\title{
Some Thoughts on the Reform of College Personnel System in China
}

\author{
Zhixiang Deng \\ Institute of Education of Jianghan University, \\ Wuhan, China \\ dzx10009@sina.com
}

\begin{abstract}
Personnel system is an important part of modern college governance. There are some problems existing in the current personnel system of colleges in China, for example, the expectations of appointment system are not achieved, the title conferring system is not perfect, and the assessment and evaluation procedures are deficient. Reasons that result in such problems include lack of strategic awareness in respect to thinking, restrictions of existing policies and laws, and insufficient incentive in the income distribution system etc. The approach of reform is to free our minds, to change our ideas, and to establish the concept that human resource is the primary resource of education, so as to actively and steadily carry forward the reform of personnel system and to improve the income distribution system.
\end{abstract}

The reform of college personnel management system is the key of establishing a modern college system. Although Chinese colleges have made a lot of efforts in exploring the reform in this respect and have achieved great results and accumulated many precious experiences, yet there still exist many outstanding problems.

Keywords—college, personnel system, reform, thoughts

\section{EXISTING PROBLEMS AT PRESENT}

\section{A. Expectations of appointment system are not achieved}

College is a unit relatively independent from the social environment with its particularity in staffing. College has poor ability in admitting its own surplus employees; besides, there is an absence of channels and approaches for mutual employment and flow of talents between college and society. It is difficult for college to discharge unsuitable employees to the society or to dismiss them. For example, if a college has to close a certain unpopular major as required by social development and market, it cannot but support the existing teachers in such major even if the teachers do not have full workload, or even if the relevant faculty is overstaffed, as long as the teachers do not offer to be transferred out. As a consequence, a college can hire teachers but cannot dismiss one, which means the post appointment system cannot be implemented.

\section{B. Title conferring system is not perfect}

The operation mechanism, management procedures and supervision system of title conferring are not scientific and reasonable and there is an absence of a standard evaluation system. By "focusing on research and pay little attention to teaching", "focusing on quantity and pay little attention to quality", "focusing on papers and pay little attention to works", promotion is mostly an internal affair and there is no pressure from external competition; no fundamental changes have ever occurred to the situation that there is only promotion and no demotion and that once appointed, one will have a permanent post.

\section{Evaluation procedures are deficient}

The particularity of jobs with respect to higher education determines the complexity of personnel management mode, and then results in the difficulty in evaluation. The objects, methods and approaches of works of various personnel such as college teacher, auxiliary staff, administrative personnel, and logistics workers are different and there are complex and various posts and duties, which affect and restrict the implementation of post responsibility system. Meanwhile, the work of some posts can hardly be quantified and evaluation indicators are hardly scientific and operable. The evaluation requirements for various personnel are not unified and the use of evaluation results in title conferring, leveling up and promotion is not comparable and scientific.

\section{CAUSES OF THE PROBLEMS}

The causes of the problems in college personnel management are complex.

\section{A. Lack of strategic awareness in regard to thinking}

The existing college personnel system retains the characteristics of planned economy. Ideas on college personnel system are lagging. College emphasizes blindly on soundness and holds a "wait-and-see" attitude, and its attraction to excellent talents is quite small, which is prominently shows by its overemphasis on stability, the dogmatism of pursuing "harmony and fairness" in traditional thoughts, and the lack of incentive measures. As for income, equalitarianism and "bigpot" system are popular and difference in pay of teachers with various workload and contributions is small, which seriously reduces teachers' enthusiasm to work. With the reform of college personnel system carried out further, the inherent contradictions gradually emerge, which requires people with 
strategic awareness to conduct top-level design of personnel system reform.

\section{B. Restrictions of existing policies and laws}

According to the classification specified in existing policies and laws, college belongs in public institution. At present the personnel management of public institutions is based on the Regulation on the Personnel Management of Public Institutions promulgated by the State Council. Although the Regulation stated that public institutions shall implement appointment system, it does not specify the supporting policies of appointment system such as pension and social insurance. Professor Yang Yansui who studies pension system has provided the following case: An old woman who has complete archives that prove her service in troops and college for several decades has gone to Guangdong to run an enterprise for 5 years. Because of job transfer and cross-area relocation, she could not receive pension as normal and her rights and interests are not safeguarded. At present the existing dual pension scheme forms a direct institutional barrier for the flow of surplus staff and unqualified personnel in college out to the society. Meantime, since college belongs in public institution and is subject to staffing restrictions, even talents that a college needs sometimes could not be appointed by the college since it has no vacant post.

\section{Insufficient incentive in the income distribution system}

The national wage management system with strong characteristics of planned economy cannot meet the requirements of modern college salary system in the socialist market economy. There is a contradiction between the diversified income distribution system and the limited fund source. Because of the separation system of financial appropriation, the method and volume of financial appropriation cannot meet the actual needs of college. Besides, the source of college post allowance is not stable and the post arrangement and evaluation system is deficient, the allowance of young backbone teachers is low and their motivation to work is insufficient.

\section{SOLUTIONS TO THE PROBLEMS}

To deepen the reform of college personnel system, we need to establish and implement the scientific outlook on development and solve the key and difficult issues in the course of college reform and development specifically according to the actual situation and characteristics of college.

\section{A. Free our minds, change our ideas, and establish the concept that human resource is the primary resource of education}

We should hold a wide discussion on personnel system reform in colleges to make clear the purpose of reform, to face up to the existing problems, to free our minds and change our ideas, and to promote scientific development. Closed ideas should be changed to open ideas, the idea of rule by man should be changed to the idea of rule by law, and the idea of balance should be changed to idea of competition. We should establish the concept that human resource is the primary resource of education, and should have the perspective required for the reform in terms of various issues such as how to properly allocate manpower and human resources, how to attract talents, and how to retain talents. We should set overall and strategic goals for reform and make innovative and operable reform plan, so as to ensure the long-term sustainable development of college.

\section{B. Promote substantial reform of personnel system actively and steadily}

College is a place where intellectuals and professional talents are gathered. Some top-level talents are irreplaceable to a certain degree. Management of such personnel is quite different from management of staff in ordinary institutions. Besides, college teachers in China form a huge knowledgeable community of interests. Especially in the Internet era, they have strong ability and various channels in regard to expression of interests. Under the background of constructing a harmonious society, the overlapping of new and old interests result in that it is impossible to formulate a perfect and rational policy for the reform of college personnel system. Further promotion of reform can only be achieved by progressive incremental reform, which is, to promote reform actively, steadily and step by step and to activate stock resources with incremental resources. In other words, on the ground of clear direction of reform, we should adopt new ideas for new employees and old ideas for existing employees, so as to actively and steadily advance the substantial reform of personnel system and to take sufficient time to achieve reform goals. Specifically, we should adopt the dual track system in the transition phase. On the one hand, we should adopt appointment system in various forms and the dual pension scheme for in-staff and off-staff employees, and overcome the staffing restrictions for public institutions by the contract system for off-staff employees, so that we could staff flexibly and enhance efficiency; on the other hand, we should also adopt a dual track system for new and existing in-staff employees, and implement a strict post appointment system and new evaluation system for new employees so as to improve the mobility of new teachers in the talents market. The benefit of dual track system is that it is good for reform, development and stability and it is suitable for exploring new system and enhancing efficiency. Its disadvantage is that it will lead to complex and more difficult management, which will cause new unfairness. Therefore, while implementing the dual track system, we should also be well aware that the dual track system is only an interim method and that the ultimate goal of institutional innovation is to establish a more reasonable single track system

\section{Highlight reform of income distribution system}

The key in reform of income distribution system is to relate income distribution with performance. With the principle of "giving priority to efficiency with due consideration to fairness", we should employ income distribution measures such as remunerating based on post, remunerating based on workload, and remunerating based on performance, and should relate the salary income of college staff with duties of post, work performance and practical contributions as well as the social and economic benefits transformed from their work 
results, so as to establish an incentive distribution mechanism step by step which values practical results and contributions and tilts towards excellent talents and key posts, and to give first-class remuneration to first-class talents with first-class performance. Meanwhile, we should make overall plans and all-round considerations; we should correctly recognize and properly handle the relationship between efficiency and fairness, implement the principle of distribution according to performance, take advantage of the leverage of interest mechanism, give priority to efficiency with due consideration to fairness, concentrate on key and important issues, and strengthen incentives to fully arouse the enthusiasm of college staff.

The reform of college personnel system is a systematic project carried out under the background of economic system transition and social transformation of China. To deepen the reform of college personnel system and to follow the laws of running a college and the laws of personnel management, we need to further eliminate the institutional barriers that stand in the way of talents development, take the psychological endurance of college staff into full consideration, strengthen institutional innovation, and establish a personnel system that fits in well with the characteristics of college, so as to arouse the enthusiasm and creativity of college staff and provide a relaxing and harmonious environment for the growth and development of talents.

\section{REFERENCES}

[1] Jin Jingbiao, Liu Bin. Review on the Studies of Protection of College Teachers' Rights and Interests in China. Modern Education Science [J]. 2010 (3): 146-149;

[2] Zhang Fusheng. "Power-centralized" system: The Evaluation of Graduate Education System of Research Universities in China. Higher Education Development and Evaluation [J]. 2010 (6): 62-68;

[3] Feng Ailing, Liu Bin. On Establishing a Diverse and Efficient Mechanism for Safeguard of College Teachers' Rights and Interests. Heilongjiang Education [J]. 2010 (2);

[4] Chen Jinling, Wang Jilin, Zhang Chunrong. A Survey on Improving the Judicial Remedy System for College Teachers' Rights and Interests. Journal of National Academy of Education Administration [J]. May, 2010: 14-19;

[5] Wang Yong. Balance and Emphasis of Several Relations in University Reform. Research and Practice on Higher Education [J]. 2011 Volume 30 Issue 4: 23-27;

[6] Xu Na, Wen Wenjun. On the Enlightenment of US Tenurial System to the Appointment System of College Teacher in China. China Electric Power Education [J]. 2011 (26): 42-43;

[7] Wen Chuan. A Literature Review on the Research of Teachers' Rights and Interests in China. Journal of Hunan University of Technology (Social Sciences Edition) [J]. December 2012, Volume 17 Issue 6;

[8] Liu Taihong. Academic Occupation, Academic Freedom and Rights of Teaching Staff in Universities. Journal of China Institute of Industrial Relations [J]. 2012 Volume 26 Issue 6: 86-90;

[9] Guo Hui. On How to Promote Teachers to Participate in College Governance - Explorations Based on the Deliberative Democratic Theory. Journal of Higher Education [J]. December, 2012: 26-32;

[10] Wu Yan. On the Establishment of Teachers' Rights and Interests Remedy Mechanism under the Appointment System of Colleges. Higher Education Exploration [J].2013 (1): 129-134 